\title{
History of the Opium Problem The Assault on the East, ca. 1600-1950
}




\title{
Sinica Leidensia
}

\author{
Edited by \\ Barend J. ter Haar \\ Maghiel van Crevel
}

In co-operation with

P.K. Bol, D.R. Knechtges, E.S. Rawski,

W.L. Idema, H.T. Zurndorfer

VOLUME 105

The titles published in this series are listed at brill.nl/sinl 


\section{History of the Opium Problem The Assault on the East, ca. $1600-1950$}

By

Hans Derks

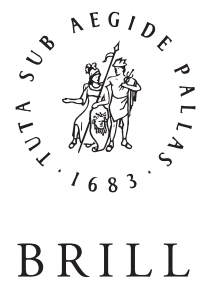

LEIDEN $\cdot$ BOSTON 2012 
This is an open access title distributed under the terms of the prevailing CC-BY-NC License at the time of publication, which permits any non-commercial use, distribution, and reproduction in any medium, provided the original author(s) and source are credited.

RII An electronic version of this book is freely available, thanks to the support of libraries working with Knowledge Unlatched (KU). KU is a collaborative initiative designed to make high quality content Open Access for the public good. More information about the initiative and links to the Open Access version can be found at www.knowledgeunlatched.org.

Cover illustration: Honoré Daumier: In China. Western Way of Trade Promotion. (Subtitle:) Inspection of the Opium Smokers, 1859 (The Daumier Website, DR Number 3101).

Library of Congress Cataloging-in-Publication Data

Derks, Hans, 1938-

History of the opium problem. The assault on the East, ca. 1600-1950 / by Hans Derks.

p. cm. - (Sinica leidensia ; v. 105)

Includes bibliographical references and index.

ISBN 978-90-04-22158-1 (hbk. : alk. paper)

1. Opium abuse-Asia-History. 2. Opium trade-Asia—History. 3. East and West.

4. Imperialism—Social aspects. I. Title.

$\mathrm{HV}_{5} 840 . \mathrm{A}_{74} \mathrm{D}_{47} 2012$

$363.45095^{\prime} 0903-\mathrm{dc} 23$

2012000057

This publication has been typeset in the multilingual "Brill" typeface. With over 5,100 characters covering Latin, IPA, Greek, and Cyrillic, this typeface is especially suitable for use in the humanities. For more information, please see www.brill.nl/brill-typeface.

ISSN 0169-9563

ISBN 9789004221581 (hardback)

ISBN 9789004225893 (e-book)

Copyright 2012 by Koninklijke Brill NV, Leiden, The Netherlands.

Koninklijke Brill NV incorporates the imprints Brill, Hotei Publishing,

IDC Publishers and Martinus Nijhoff Publishers.

All rights reserved. No part of this publication may be reproduced, translated, stored in a retrieval system, or transmitted in any form or by any means, electronic, mechanical, photocopying, recording or otherwise, without prior written permission from the publisher.

Authorization to photocopy items for internal or personal use is granted by Koninklijke Brill NV provided that the appropriate fees are paid directly to The Copyright Clearance Center, 222 Rosewood Drive, Suite 910, Danvers, MA 01923, USA.

Fees are subject to change.

This book is printed on acid-free paper. 


\section{CONTENTS}

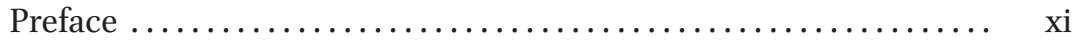

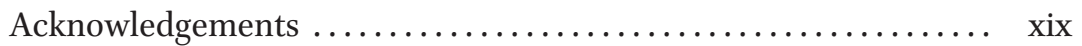

List of Illustrations, Tables, Figures and Maps $\ldots \ldots \ldots \ldots \ldots \ldots$ xxi

\section{PART ONE. THE OPIUM PROBLEM}

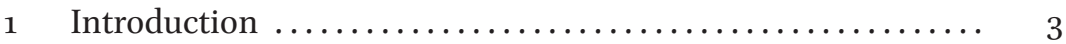

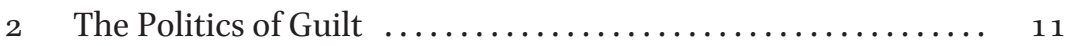

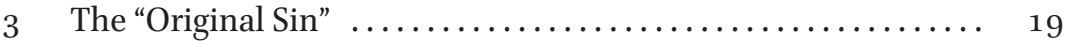

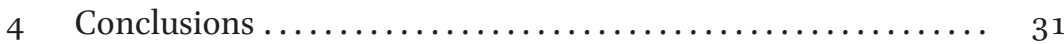

PART TWO. THE BRITISH ASSAULT

5 The Actual Sins . . . . . . . . . . . . 35

A Private English Asian Trading Company ............ 37

Opium on a List ........................ 40

A Moral Question .......................... 46

6 Tea for Opium Vice Versa $\ldots \ldots \ldots \ldots \ldots \ldots \ldots \ldots \ldots \ldots \ldots \ldots$

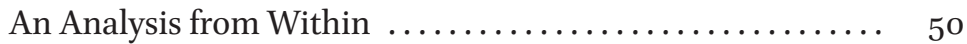

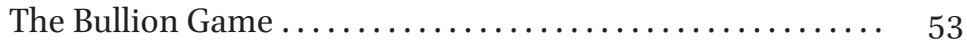

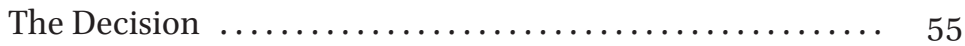

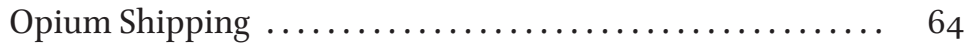

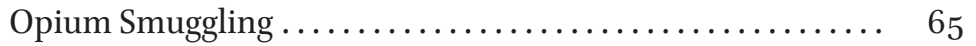

Opium Corruption $\ldots \ldots \ldots \ldots \ldots \ldots \ldots \ldots \ldots \ldots \ldots \ldots, 68$

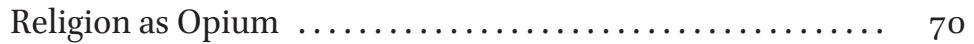

Opium Banking in a Crown Colony ............. 72

Exorbitant Opium Revenues ................. 77

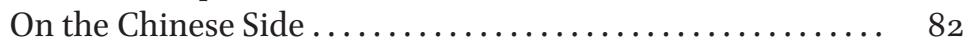

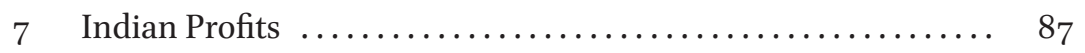

Monopoly Opium Production ................. 88

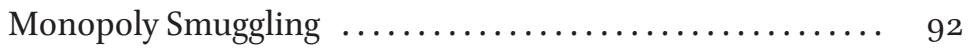

A Western Competitor......................... 95

Narco-business Revenues .................... 98

8 The Invention of an English Opium Problem ............ 105

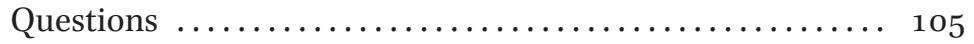

An English Home Market for Drugs .............. 107 
The Creation of the English Opium Problem .......... 113

\section{PART THREE. THE DUTCH ASSAULT}

Portuguese Lessons

Portuguese Elite versus Portuguese Folk ............. 137

Arab Trade in Peace ........................ 141

On the Malabar Coast ...................... 146

What Did the Dutch learn about Opium from the Por-

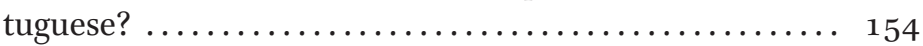

11 Pepper for Opium Vice Versa .................... 163

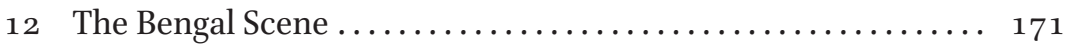

The Dutch Connection ..................... 175

Mughal Production and Consumption ............ 179

13 The "Violent Opium Company" (VOC) in the East ......... 189

A "Heart of Darkness" avant la lettre ................ 189

The Dutch Opium Image .................. 191

Laudanum Paracelsi ....................... 191

The Sailor's Health ...................... 195

The Asiatic Opium Image of the Dutch $\ldots \ldots \ldots \ldots \ldots \ldots . \ldots$

Double Dutch Violence ...................... 202

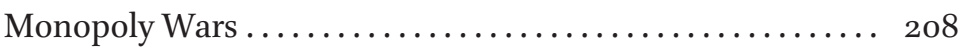

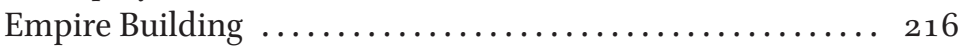

The Banda Case and all that $\ldots \ldots \ldots \ldots \ldots \ldots \ldots \ldots \ldots$

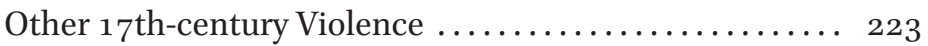

Continuous Dutch Violence .................. 226

Dutch Opium Trade: General Questions ............ 227

The Indigenous Producers $\ldots \ldots \ldots \ldots \ldots \ldots \ldots \ldots \ldots . \ldots \ldots 231$

Opium Consumption in the East Indies $\ldots \ldots \ldots \ldots \ldots \ldots 234$

14 The Amphioen Society and the End of the VOC ........ 239

A Brilliant Economist? ....................... 242

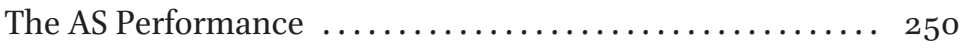

15 The Chinese, the VOC and the Opium .............. 255

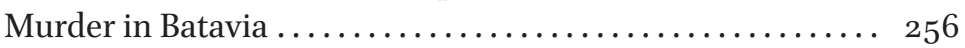

Birth of a Chinese Hate? .................. 259

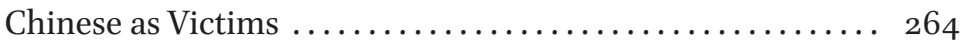

Chinese and Early Opium Trade ............... 271

16 From Trade Monopoly into Narco-State Monopoly .... . . . . 277

A Transformation from Private into Public Interest ...... 278 
The Four Van Hogendorps as Opium Dealers ......... 281

The Birth of a Narco-military State ............. 286

17 Tin for Opium, Opium for Tin? .................. 295

The Opium Business of Billiton ................ 302

18 Public Adventures of a Private State within the State ...... 307

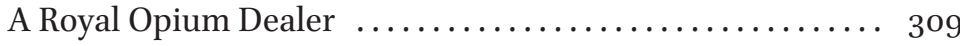

The State within the (Colonial) State ............. 313

19 The Opium Regime of the Dutch (Colonial State), 1850-1950 319

The Outer Districts ......................... 319

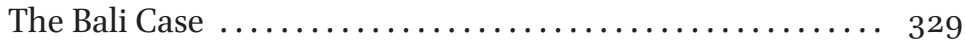

The Opiumregie .......................... 333

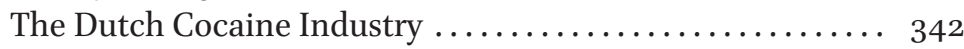

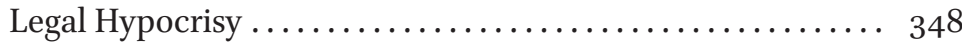

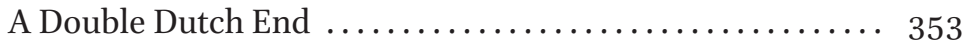

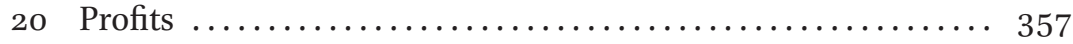

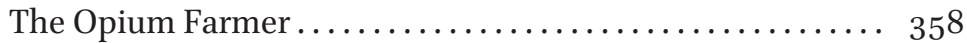

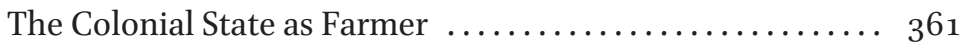

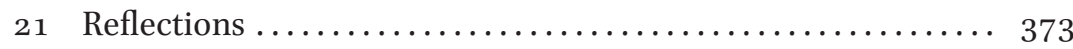

\section{PART FOUR. THE FRENCH ASSAULT}

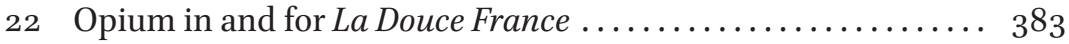

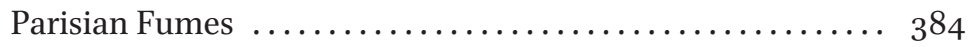

The French Pharmaceutical Scene $\ldots \ldots \ldots \ldots \ldots \ldots \ldots . \ldots \ldots$

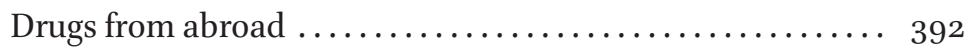

23 The French Colonial Scene in Southeast Asia ........... 395

The Beginning of a Disaster ................... 397

The French Opium Performance ............... 400

Revenue Farming ........................ 401

The Opiumregie ......................... 406

The French Concession in Shanghai .............. 411

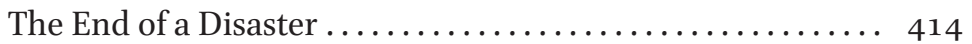

24 The Southeast Asian Context .................. 417

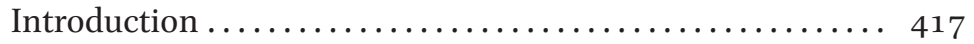

From "Golden Triangle" to "Bloody Quadrangle" ........ 420

The Tribal Scene ......................... 424

The Shan State......................... 427

The Hmong Tribe ....................... 431

Consumption Pattern $\ldots \ldots \ldots \ldots \ldots \ldots \ldots \ldots \ldots \ldots \ldots \ldots$ 


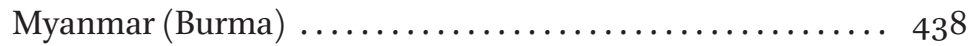

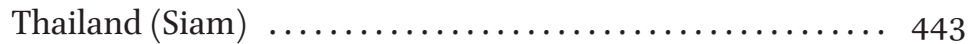

Malaysia (Melaka, Malacca) and Singapore .......... 447

25 The Role of the Chinese in Southeast Asia ............. . 459

About an "Identity" of Chinese Migrants .............. 459

The Chinese Settle(ment) Strategy .............. 464

The (pre-)History of the Chinese Opium Performance . . . . 467

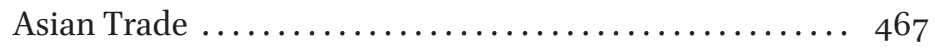

'... their industry and economy ...' ............. 469

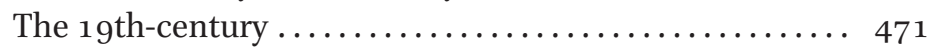

The Rich "Overseas Chinese" and Opium Criminality ..... . 473

The Rich .......................... 473

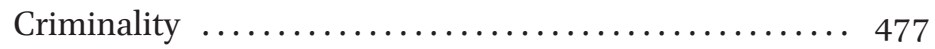

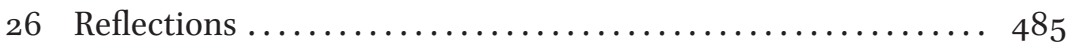

\section{PART FIVE. THE NEW IMPERIALISTS}

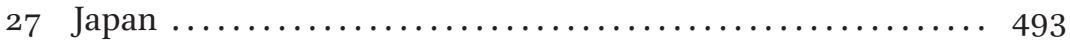

A Domestic Opium Problem ................... 495

The Annexation of Formosa/Taiwan .............. 498

A Former Formosa ....................... 499

A "New Formosa" ....................... 502

The Korean Case ........................ 509

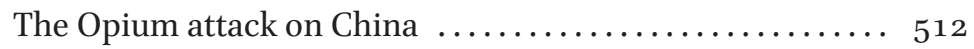

The 'Roaring Twenties' .................... 512

From World Economic Crisis to World War II ........ 516

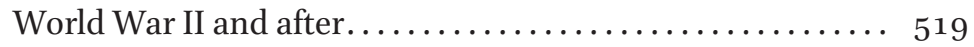

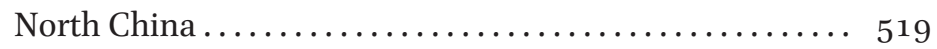

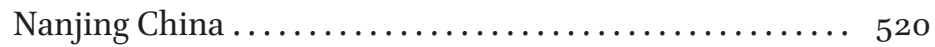

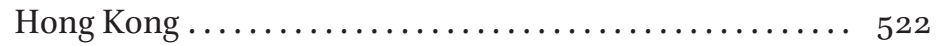

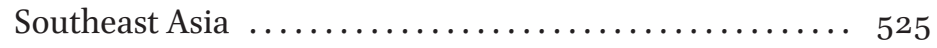

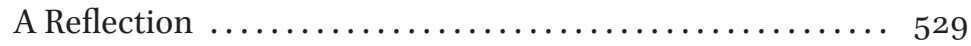

28 United States of America . . . . . . . . . . . . . . 531

A Domestic Opium Problem from the Early 19th-century? . 531

Rise and Direct Decline of "Free Trade" ............ 537

American-Chinese Opium relations, 180o-ca. 1865 ..... 542

The "Mystery" of the Chinese Opium Import . . . . . . . . . 545

The Creation of a Chinese Threat after $1911 \ldots \ldots \ldots \ldots . \ldots 51$

A first "War on Drugs" and its Limitations ............ 554 
The Philippine Case ........................... 559

Early 2oth-Century Opium and Cocaine Consumption .... $55^{67}$

A Basic Drink ............................... $55^{67}$

Basic Knowledge $\ldots \ldots \ldots \ldots \ldots \ldots \ldots \ldots \ldots \ldots \ldots \ldots \ldots \ldots$

A Mega Consumption ........................ 572

Cocaine Connections ......................... 577

Basic Instincts .............................. 581

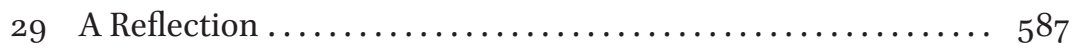

\section{PART SIX. THE VICTIMS}

3o Blaming the Chinese Victims ....................... 593

Introduction ................................ 593

An original image $\ldots \ldots \ldots \ldots \ldots \ldots \ldots \ldots \ldots \ldots \ldots \ldots \ldots \ldots$

The Addict "by nature" ...................... 601

Who and How in the Chinese Opium Scene ........... 605

The Religious Assault .......................... 609

Racism ................................... 619

31 The West and its Opium Import in China $\ldots \ldots \ldots \ldots \ldots \ldots 627$

A British Inspector ... .......................... 629

... and his American Heirs . .................... 637

32 Opium Production and Consumption in China ............ 643

The Healers and the Poppy $\ldots \ldots \ldots \ldots \ldots \ldots \ldots \ldots \ldots . \ldots 644$

The Judge and the Poppy ...................... 654

Chinese Republican Opium Production .............. 657

Yunnan Opium Production and Trade ............... 666

Chinese Opium Consumption ................... 671

About Opium Gangsters ........................... 682

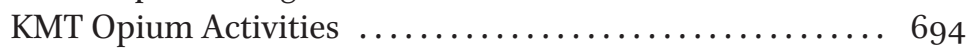

A Mao Opium Case? ............................... 699

33 A Reflection .................................. 709

PART SEVEN. THE STORY OF THE SNAKE AND ITS TAIL

The Problem .................................. 711

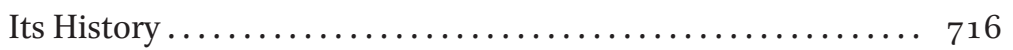

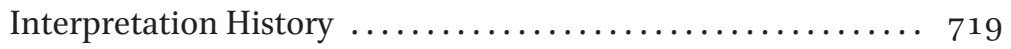

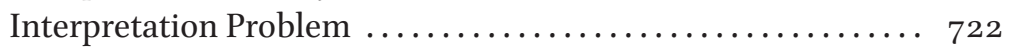

What Could Be Done? ......................... 729 


\section{APPENDICES}

Appendix 1 From Rags to Riches to Rags, ca. 1775-1914...... 735

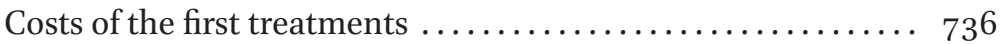

Production of opium in India and its market prices . . . . . 737

The work in a British opium factory in India $\ldots \ldots \ldots \ldots \ldots 738$

Public sales .......................... 739

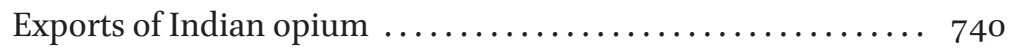

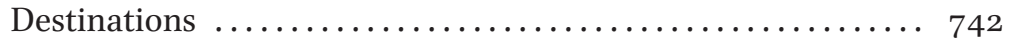

EIC ships from Calcutta to Canton, $1775^{-1820} \ldots \ldots \ldots \ldots \ldots 748$

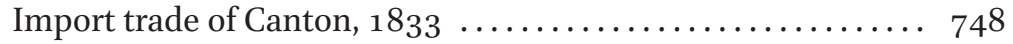

Prices of opium, $1800-1914 \ldots \ldots \ldots \ldots \ldots \ldots \ldots \ldots \ldots \ldots \ldots$

Appendix 2 The Dutch Opium Import, $1678-1816 \ldots \ldots \ldots \ldots 753$

Appendix 3 The Amphioen Society Swindle ............ 757

Appendix 4 From VOC Opium to Raffles' Heritage ......... 759

Appendix 5 The French and Dutch Opium Factories ........ 765

GLOSSARY $\ldots \ldots \ldots \ldots \ldots \ldots \ldots \ldots \ldots \ldots \ldots \ldots \ldots \ldots \ldots \ldots \ldots \ldots \ldots \ldots \ldots \ldots$

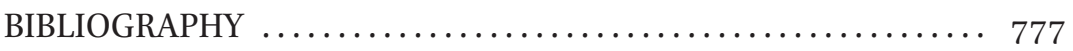

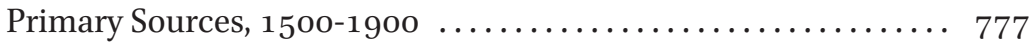

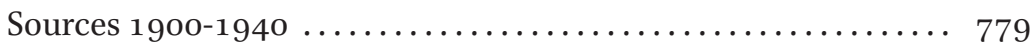

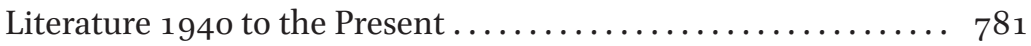

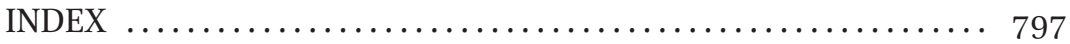




\section{PREFACE}

How came any reasonable being to subject himself to such a yoke of misery, voluntarily to incur a captivity so servile, and knowingly to fetter himself with such a sevenfold chain?

Thomas De Quincey, Confessions of an English Opium Eater (1821).

Today some ... call the U.S. invasion of Iraq the greatest strategic military disaster in American history, a massive squandering of lives and resources that will affect the Middle East and reduce the power of the United States ... Yet compared with what is at stake in Afghanistan and Pakistan, Iraq may well turn out to be a mere sideshow ... The U.S. failure to secure this region may well lead to global terrorism, nuclear proliferation, and a drug epidemic on a scale that we have not yet experienced and I can only hope we never will.

Ahmed Rashid, Descent into Chaos (2009), p. xlii

De Quincey's idiosyncratic confession was recently (2009) reissued in a series entitled "Great Ideas". Certainly after reading the following text, one can doubt how "great” De Quincey's idea was. That is not our concern, but how should we label the idea of answering the same question by altering 'himself into 'others' or, more precisely, 'oppressed (and, therefore, involuntary) others' ? That is, indeed, exactly the question dealt with in the following history: why, when and how are foreign people enslaved by making them opium addicts?

The use, trade, chemistry or effects of opium are not a blank page in historiography, anthropology, economics, chemistry or medical sciences, let alone in practical politics and political morality. Books and articles have been written on all these of separate aspects of the phenomenon, mostly by experts and published in not very popular publications. They seldom cover the relationships between all or the most relevant aspects over a sufficiently long stretch of time, so that experts easily lose sight of the larger dimensions of the Opium Question. 
However, the most serious failures of the bulk of these publications are the stringent victim approach (poor addicts who must be cured at great cost) and a fundamental distortion of history. Typical sentence:

In an Egyptian medical treatise of the sixteenth-century B.C., Theban physicians were advised to prescribe opium for crying children just as, three and a half millennia later, Victorian babies were dosed with the opiate Godfrey's Cordial by their nurses to keep them quiet. ${ }^{1}$

Apart from the untenable historical comparison, this leads either to a popular historiography of opium use and the effects of addiction with botanical knowledge about poppy growing, or to one in which the victims (mostly Chinese) are transformed into the perpetrators through a combination of ignorance, prejudice and, eventually, ideological blindness. Unprovable references to remote historical situations are too often used as legitimating the production, distribution and consumption of opium and other drugs. The assessment of these products is also distorted, when isolated from their historical, social or cultural contexts. Finally, one has to acknowledge, that the times of Euro- or Western- centred-historiography are definitely over, which automatically implies that the darker sides of European history shall be stressed more.

Many examples will be given to illustrate all this. A most recent and curious one offered by serious historians - which does not show all of these "misunderstandings" — is the following:

Chinese consumers and their merchants and middlemen created the market for imported opium, which was thought to be superior to the domestic supply that had earlier provided the major source. ${ }^{2}$

At least four serious mistakes are made in one sentence: (1) as we will prove in all possible detail, the Chinese opium market was created by Western colonizers and imperialists, in particular the Dutch, English and American dealers, smugglers, etc. and their militant governments; (2) Chinese poppy cultivation and/or opium production was started after this Western assault was successful and after Western coastal colonies in China were established; (3) there was no Chinese domestic supply before the Westerners started their Opium Wars, let alone an inferior one; (4) if one writes about 'imported opium', then one may expect that it is not available in China (in sufficient quantities), while import was nearly

\footnotetext{
1 A. Hayter, Opium and the Romantic Imagination (London: Faber, 1971), p. 19.

2 R. Murphy, K. Stapleton, East Asia. A New History (Boston: Longman, 2010), p. 167.
} 
always done by foreign (in this case: non-Chinese) importers: who, then, must have created 'the Chinese market for imported opium'?

To avoid all those mistakes and misinterpretations a new approach is introduced, namely to describe and analyze the History of the Opium Problem. This is a history of the production, consumption and distribution of opium and its derivatives from the time they form an objective political, social, economic or cultural problem in a specific period and place. The first time that this happened in world history, one of the theses of this study, is on the west coast of India (Malabar or Kerala) after 1660 due to the Dutch assault in the framework of the establishment of their Asian trade empire.

The practical consequences of the Dutch opium policy at the time were far-reaching; even so, in hindsight, it must have had a world-historical significance, because all other opium-imperialists followed the Dutch example to some extent. In addition, we can establish that before this "moment" no opium problem existed, although there was always some narcotic consumption. This has marked consequences for a historiography covering the substantial moral exploitation of opium use and its problems. Furthermore, a definition of Opium Problems is derived from the practical features "in the field", not based on some theoretical or ideological stand.

The following History of the Opium Problem takes a perpetrator's point of view, although it is impossible to forget the victims. Apart from the Asian perspective,attention is also paid to an autonomous early internal European opium trade and the household consumption of opium. The intention is to discuss, whether this is problematic as well.

However, the main focus will be on the Opium Question as a creation of Western imperialism and colonialism in Asia. This is not a result of some ideological standpoint, but simply a consequence of proper historical and political-economic research.

It is natural to compare this Western opium assault on the East to slavery between Africa and the Americas. This would not be an exaggeration. ${ }^{3}$ The "coolie labor" in the 19th-century was already similar to African slave

3 The most cruel perpetrators, the Calvinist Dutch, did both in the most extreme manner, but even their zealous attempts failed to develop a slave trade in the East as large as that in and between Africa and the Americas (see part 3). They created a new form of slavery as K. Ward analyzed and described: empire building through forms of forced migrations, penal transportation, "legalized" slave trade. In this way the Cape of Good Hope colony developed into a penal colony long before the English designed Australia in the same format or long before coolie labor became popular. 
labor for contemporaries. The latter was, however, not directly accompanied by the opium trade, which was the case in the coolie trade, often involving the same traders and coolie-holders.

This history still seriously burdens the relationship of the West and the East today, which is too often characterized by wars and serious repressions, of which the two Opium Wars in the 19th-century or the Pacific part of World War II may be the most spectacular. However, from about 1500 onwards, there were hundreds of warlike conflicts started by the West against the East (almost never the reverse: "Pearl Harbor" was the second time in a millennium!), sometimes of a genocidal character.

Ahmed Rashid's quotation above refers to the two wars the Bush and Obama administrations are fighting at present with their English or Dutch allies. The Afghanistan war is definitely a new Opium War from which Rashid hopes that it will not lead to a global 'drug epidemic on a scale that we have not yet experienced'.

Astonishment about this Western behavior is not the only motive to write his bestseller. Rashid:

Above all, arrogance and ignorance were in abundant supply as the Bush administration invaded two countries in the Muslim world without any attempt to understand the history, culture, society, or traditions of those countries. ${ }^{4}$

Without exaggerating the performance of the Bush family, Rashid's remarks about the present political conduct must be an Aha experience for a historian of the Opium Problem. Time and again this astonishment was the reaction seen when writing about the opium history from 1500 onwards. It could make readers pessimistic and impatient, but I still hope that this story will help to stamp out this 'arrogance and ignorance' and, more importantly, to avoid the 'drug epidemic' Rashid predicts.

For several reasons explained in the first part of the study, this history of the opium problem is not a history of opium use or poppy culture. It starts around 1500 with the Asian activities of the Portuguese in particular. As indicated above, it is the Dutch narco-military machine starting a good century later which plays its lesser-known key role (part 3). Of course, the story is often told of how through the Opium Wars the English imperialists addicted China in the middle of the 19th-century (part 2). They learned this largely from the Dutch and brought it to its logical conclusion by addicting China.

\footnotetext{
4 A. Rashid, Descent into chaos (London: Pelican Books, 2009), p. xlii.
} 
The British and French went further, with the important assistance of American smugglers and their clippers. From their "possessions" in China and Southeast Asia, certain innovations in opium management were introduced. They exported, furthermore, to the other side of the Pacific, the USA, and the opium snake started to bite its own tail. Both are largely responsible for leaving a heritage of present production centers in Southeast Asia and the Middle East of world-economic importance. A new cycle of exploitation and repression of the minds of the people started, which could eventually be followed-up by Rashid's 'drug epidemic'.

This is my outline of the main thesis of the following study. A second thesis shows its limitations.

From the very beginning of the Portuguese and, certainly, the Dutch opium assault on the East, it becomes evident that the decision-makers were well informed about the very nasty effects of opium on the minds of people. They even detested the opium users and prohibited their own people from using it on penalty of serious punishments. Therefore, ignorance can only apply in a limited way to most implementers of the decisions made, but not to most authorities of the time. The moral protests in most Western countries starting during the second half of the 19th-century against opium use, smoking and addiction have, therefore, a soundly hypocritical character.

In addition, they were too late. New drugs like heroin or morphine, derived from opium but with much more devastating effects, were being distributed while people still worried about the comparatively innocent activity of opium smoking. In the 19th-century a new kind of moral agent, representatives of the medical professions (from hospital doctors to apothecaries), counterattacked the anti-opium complaints. As will be demonstrated, they started to defend its usefulness while prescribing its products wholesale. The new chemical and pharmaceutical industries in Europe and the US became the nearly invincible economic interests to support the modern narco-military machines.

Now, the Western gate was opened for the Trojan horse of the narcomilitary opium industry and their ravaging warriors, the drug-dealers with their supporters in the state and local bureaucracies. The other side of this coin is that the classic Asian opium production (India) and consumption (China, Southeast Asia) lands are largely liberated of the evil. What remains there as regions of production (Afghanistan and Myanmar) is nearly fully dependent on Western consumers. 
This is, in short, the second chain of arguments of this study. With both chains, several important details are discussed in their historical or politico-economic contexts: the role of the state (military, violence, wars, prohibitions, etc.); the ideological institutions (religion, churches, missionaries, value systems, etc.); the narco-dealers with their tactics and support; the modern industrialization; the astronomical profits; the effects on foreign policies and other features.

There are also limits to this study since it is not possible to deal with all of the perpetrator or victim countries. The main focus will be on the British, Dutch and French imperialist opium activities in China, India and Southeast Asia, including their function as models for the New Imperialists, Japan and the USA. Since the opium history of the present Indonesian archipelago is not well known outside Dutch archives and some Dutch expert publications, it is treated here in great detail for the first time in English.

This preface ends with some technicalities. The aim of this large global and interdisciplinary study is also to make a new kind of handbook for students of the opium problem. It is the first time that such a book has been written, which implies that it has a certain experimental and introductory character. A study about a historical, social, economic, etc. problem like opium, compared rightly by many to slavery, is by definition "controversial". Although slavery is recurring, alas, in several areas at present, it does not have the same social and economic impact as in the 16th19th-century. The Opium Problem, which originated almost the same time, has in fact increased century after century. It is massively present throughout the whole world. It stands now, of course, also for its derivatives as heroin and morphine, while the cocaine problem is also addressed in passing. In the media and elsewhere it daily leads to highly contradictory arguments and actions.

Certainly with this subject, any author is unable to come up with a value-free description, analysis or judgment. It must be "enough" that no description or analysis is given without a careful argumentation, indication of the sources used, etc.

A handbook presupposes the availability of a broad range of data and that is true in this case as well. This is, furthermore, guaranteed by the method used known as Gesellschaftsgeschichte (H.-U. Wehler and others). In many parts new archival material could be used, while the attempt is made in the numerous quotations to reproduce original voices in time 
and place. These quotations are, therefore, relatively extensive. There are, at the moment, few publications with so much quantitative data over such a long period. Extensive appendices are used and many notes point time and again to alternative interpretations and literature. The result is a specific insight in the socio-economic relations of many countries over a period of several centuries.

The other side of this picture is that many geographical and other names in the quotations and elsewhere are unknown in present spelling and that exotic currencies are often difficult to compare. A glossary is only of limited use to avoid misunderstandings in these fields.

Chronologically, the Dutch assault on Asia occurred about a century earlier than the English one. The latter is chosen, however, as a kind of model for the whole study. Its story is better known, although probably some new vistas are opened on it. In addition, the reader can become more familiar with the-probably unexpected-complexities, which are detailed in the other chapters and parts.

A practical problem of this history is, of course, where to stop. Several logical possibilities were available. Anonymous readers advised stopping immediately after World War II. Many events in a History of the Opium Problem indeed came together around that period: the liberation from colonial exploitation of countries like Indonesia, Burma (Myanmar), China, India, etc. These countries played a pivotal role in this history. Finishing an opium history in 2011, inevitably leads to commemorate the important revolution of 1911-1912. A first promising attempt to solve the very extensive Chinese Opium Problem, however, just failed (see ch. 31). This happened not in the least because one had to deal not only with the addiction of a substantial part of the population, but with a most serious political, social and economic problem. One definitely succeeded to solve such an Opium Problem around 1950 for the first time in history, thanks to the victory over the fully opium contaminated Nationalists. For all these reasons "1950" became the end of this history, with the hope that a followup to the present can be made someday.

Hans Derks

www.hderks.dds.nl

October 2011 
Hans Derks - 9789004225893

Downloaded from Brill.com@4/26/2023 03:28:55PM via free access 


\section{ACKNOWLEDGEMENTS}

Many people have helped (in)directly make this book a reality. Indirectly, I owe much to three inspiring spirits who accompanied many of my previous historical and sociological studies personally and in their writings: Bernhard Slicher van Bath, Hans-Ulrich Wehler and Wim Wertheim. The first showed me the intriguing possibilities of quantitative historical research; the second of integrating historical and sociological approaches; the third of the new perception needed for studying the history and society of China, Indonesia and other Asian societies. All of them taught me to paint the historical picture on a large canvas, so that I also discovered what the political philosopher Hannah Arendt demonstrated that, as modern man, the world should be your home.

Directly, this study has been helped not only by the scholarly advices of Frank Bovenkerk but particularly by the highly stimulating comments of Lars Laaman of London University, who critically reviewed the whole manuscript. Furthermore the invaluable help of Alison Fisher should be mentioned, who did a good job in editing my English.

Of course, the initial trust of the staff of publisher Brill, Albert Hoffstädt and Marti Huetink, in this large project was of pivotal importance to realize this History of the Opium Problem. Its very professional team of Patricia Radder and Wilma de Weert has seen this large project through the daily process of production. All of them must be thanked wholeheartedly.

The same is appropriate for the editors of the series Sinica Leidensia, Barend ter Haar and Maghiel van Crevel, to allow the publication of this history as volume 105 .

Furthermore, I would like to thank all those publishers allowing us to use copyright material. In particular, I have to mention Cambridge University Press and Harvard University Press for granting permission to use maps, figures and illustrations as indicated in the text.

Last but not least, this book could not have been written without the continuing support of my wife and children, to which this book is dedicated. 
Hans Derks - 9789004225893

Downloaded from Brill.com@4/26/2023 03:28:55PM via free access 
LIST OF ILLUSTRATIONS, TABLES, FIGURES AND MAPS

\section{ILLUSTRATIONS}

1. Papaver Somniferum, Bently \& Trimen, $1830 \ldots \ldots \ldots \ldots .4$

2. Frontispiece from Itinerario, Jan Huygen van Linschoten,

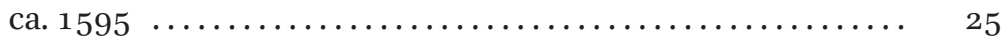

3. The Opium War and China in the cartoons ........... 42

4. Patna, India: four interiors of an opium factory; "mixing",

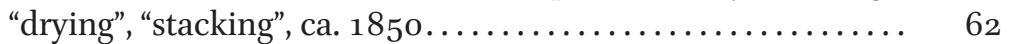

5. Battle at Canton, ca. $1845 \ldots \ldots \ldots \ldots \ldots \ldots \ldots \ldots \ldots \ldots \ldots \ldots \ldots$

6. The Pharmacist's Competition, ca. $1866 \ldots \ldots \ldots \ldots \ldots \ldots . \ldots \ldots$

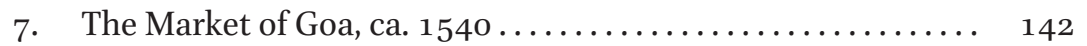

8. People from the Malabar Coast ca. $1600 \ldots \ldots \ldots \ldots \ldots \ldots .156$

9. Destruction of three Portuguese galleons at the Malabar coast,

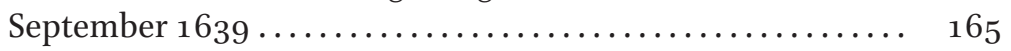

10. Venice and its Treacle ....................... 193

11. List of Medicines in the Ship's Doctor's Chest, ca. 1660 . . . . 195

12. Several Amputations and the Cauterization of Wounds, 1657197

13. Cargo List of nine homewardbound Eastindiamen, 1690 . . . 209

14. Revolts and Massacres ..................... 225

15. Funeral Procession of a VOC Governor-General, $1761 \ldots \ldots .249$

16. The Dutch Massacre of the Chinese, Batavia, 8 October 1740 . 257

17. Coolie Labor in the Dutch Tin Mines, $1919 \ldots \ldots \ldots \ldots \ldots \ldots$

18. Interior of the Opium factory, Batavia ca. $1935 \ldots \ldots \ldots \ldots \ldots 337$

19. Dutch Cocaine Factory, copy of a share $1942 \ldots \ldots \ldots \ldots \ldots .344$

20. A Chinese junk amidst Southeast Asian and European vessels,

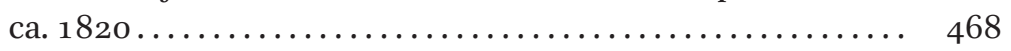

21. Japanese Overlords and their civilized Savages, Formosa

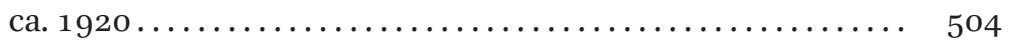

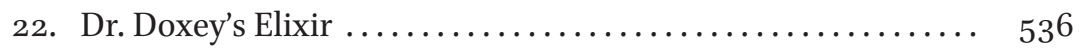

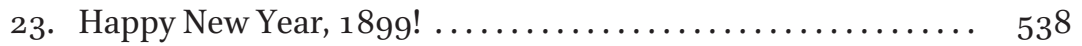

24. A Skeleton in his Closet ..................... 546

25. "The Harvest in the Philippines", $1899 \ldots \ldots \ldots \ldots \ldots \ldots \ldots$. 560

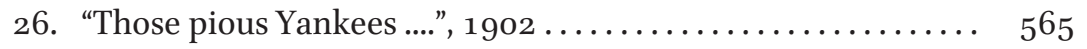

27. Coca Cola: old and new claims................. 568

28. How to dope US. babies ca. $1870 \ldots \ldots \ldots \ldots \ldots \ldots \ldots \ldots \ldots \ldots$

29. Bayer Pharmaceutical Products, $1898 \ldots \ldots \ldots \ldots \ldots \ldots \ldots . \ldots 79$ 
30. Open Air Preaching, $1892 \ldots \ldots \ldots \ldots \ldots \ldots \ldots \ldots \ldots \ldots \ldots 611$

31. The Yellow Terror, ca. $1900 \ldots \ldots \ldots \ldots \ldots \ldots \ldots \ldots \ldots \ldots .620$

32. 'Quan shi jieshi dayan wen' (Essay urging the World to give up

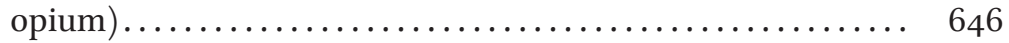

33. The Manufacture of Opium in India, $1900 \ldots \ldots \ldots \ldots \ldots . \ldots 742$

\section{TABLES}

1. Trade between England, China and "British" India, 1800-1900 77

2. India's Foreign Trade in select items by Value, $1849-1850$ in $£$

3. Balance of Trade of "British" India with selected countries,

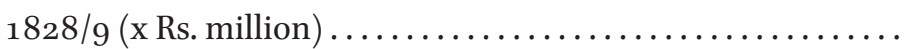

4. Opium Revenues and Expenditures of British Colonial Government in India ............................. 100

5. Value of Main Export Products from "British" India in selected years, $1813^{-1930}$ (Rs. million) .................. 102

6. Exports of Raw Opium from "British" India to Asian Countries, 1922-1935 (in chests)....................... 103

7. Sources and Quantities of England's Opium Imports, 1827-

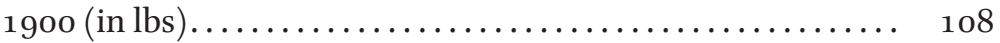

8. Import of Opium in Germany, 1910-1925 ( x 100 kg) ...... 109

9. Bengal Opium Exported to the Malabar Coast, 1657-1718 (selected years; in Dutch pounds).............. 170

10. Bengal Opium Exported to the East Indies Archipelago, 16591718 (selected years; in Dutch pounds) ............. 178

11. 'Contributions to the Dutch Indies Government by the Billiton District', $1864-1920$ (in guilders).................. 298

12. Profit and Loss Account of the Royal Dutch Trade Company, 1824-1834 (selected years; $x$ 10oo Dutch guilders)..........

13. Net Output of Opium Leasing in Outer Districts of the East

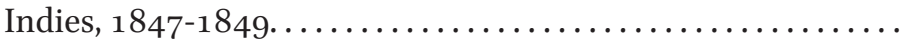

14. Opium consumption (in thails) of License- and Non-License Holders in Java, Madura and Outer Districts (Buitengewesten)

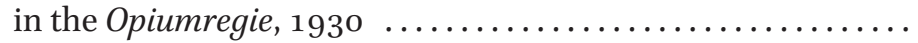

15. Income and Expenditures of the Opiumregie and the Colonial State, 1920-1931 (x 1000 Dutch guilders) ............ 339

16. Coca Leaves Export from Java, 1904-1940 (selected years) . . 342

17. Stocks of Coca Leaves, 1933-1938 (x 1 kilogram) ..........

18. Prices, Profits and Quantities of Opium of the Opium Farmers in 1887 
19. Dutch Government Net Opium Profits in the East Indies,

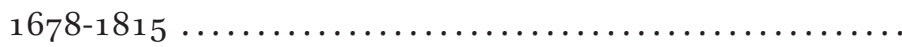

20. Dutch Government Opium and Colonial Profits in the East

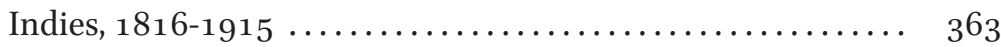

21. Profits from Colonial Products, $1848-1866 \ldots \ldots \ldots \ldots \ldots .364$

22. Opium import in Batavia, 1881-1883 in chests and in guilders 368

23. Contribution of the Opiumregie to the Government Budget in the East Indies, 1914-1940 (x 1 million current Dutch guil-

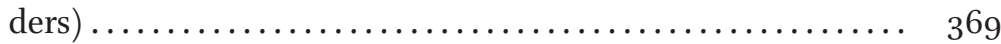

24. Dutch trade and Yield in Opium in the East Indies, 1914-1932 371

25. Opium sold to and Income from Revenue Farms in Cochin-

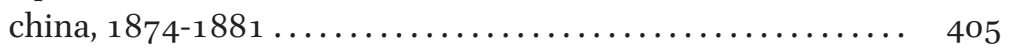

26. Rentability of the Opiumregie compared to the Farm-system

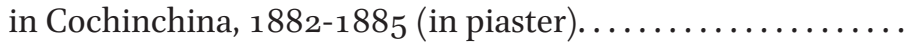

27. Costs and Revenue of French Opiumregie in Cochinchina, 1882-1898 (x 1000 piaster)...................... 408

28. Southeast Asian Opium Cultivation and Heroin Production,

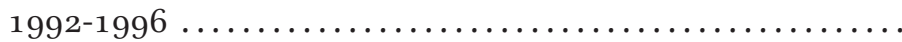

29. Comparison between "legal consumption" of opium in Southeast Asia and the Chinese coast, ca. 1930 ............. 434

30. Opium smokers in Indochina in $1906 \ldots \ldots \ldots \ldots \ldots \ldots$

31. Estimated Number of Opium Addicts and Consumption of Illicit Raw opium in Indochina and Singapore-Malaya, 1955

32. Value of Estimated Exports of Opium from Burma to Thailand

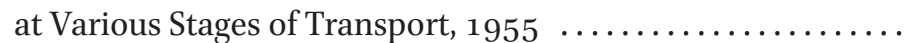

33. Singapore Opium Farm Annual Rent, 1820-1882 (selected

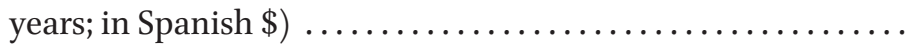

34. Estimated monthly costs and sales of selected Malayan opium

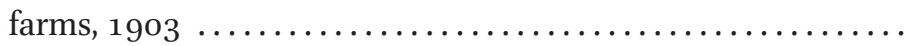

35. Raw Opium Seized in Singapore by Country of Origin and Value opium import, $1954-55 \ldots \ldots \ldots \ldots \ldots \ldots \ldots \ldots$

36. Opium revenue and Licensed Opium Smokers on Formosa,

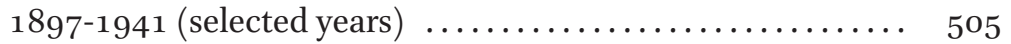

37. Japanese Cocaine Production, $1934-1939$ (x 1 kg) ........ 509

38. Opium and Narcotics production in Korea, 1930-1941 .... 511

39. Annual Import of Opium into Tianjin around $1936 \ldots \ldots \ldots \quad 516$

40. Mengjiang Opium Export, 1939-1942 $\ldots \ldots \ldots \ldots \ldots \ldots \ldots .520$

41. Pacific opium import and duties paid in USA and Canada, 1871-1899 (selected years) $\ldots \ldots \ldots \ldots \ldots \ldots \ldots \ldots \ldots$ 
42. Atlantic Opium Imports and Duties Paid, 1871-1899 (selected

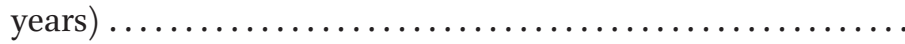

43. Total Import of Opium and Opium Preparations to the USA, 1850-1924 (selected years) $\ldots \ldots \ldots \ldots \ldots \ldots \ldots \ldots \ldots \ldots \ldots \ldots \ldots \ldots$

44. U.S. coca imports: medicinal (cocaine) and non-medicinal (cola), 1925-1959 (x kilogram) .................. 578

45. Merck Production and its German Import of Cocaine and Coca,

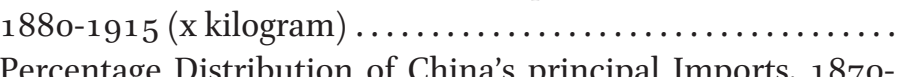

46. Percentage Distribution of China's principal Imports, $1870^{-}$

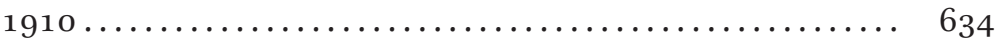

47. Trends in crop acreages between 1904-9 and 1930-3 ..... 661

48. Commodity composition of maritime Customs trade in 1908

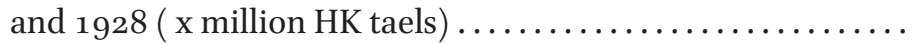

49. Opium Smokers in Cantonese Rehabilitation Centers, 1937 and

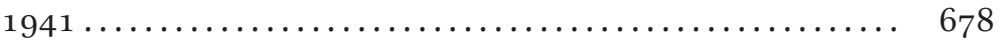

50. A Supply Side of the Opium Problem Around 1970 (in US\$) . $\quad 728$

51. Expenses and profits of cultivating one bigha of Malwa opium

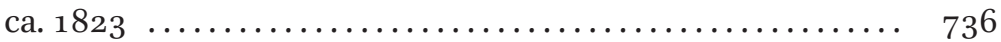

52. Production and Prices in Indian districts and Calcutta in piculs and guilders, $1873^{-1882} \ldots \ldots \ldots \ldots \ldots \ldots \ldots \ldots$

53. Public Sales of Bengal Opium of the EIC in Calcutta, 1787-

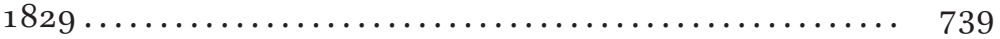

54. Exports of Opium from India in chests, $1829-1902 \ldots \ldots \ldots 740$

55. Bengal Opium Export after Sales from India and Financial results of EIC and Government of India, 1787-1900 .......

56. Export of Bengal Opium from Calcutta to Several Destinations, 1809-1850 in chests (selected years) .............. 744

57. Export of Malwa Opium from Bombay to Several Destinations, 1809-1850 in chests (selected years) .............. 745

58. Growth of Opium Trade in Ceylon (Sri Lanka), 1840-190o in lb 746

59. The Opium Smuggling of Singapore, $1835^{-1865}$ in chests

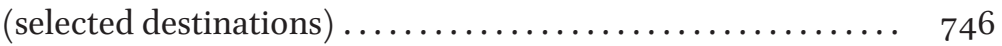

6o. "British" Indian Export of Opium to Various Countries, 1911-

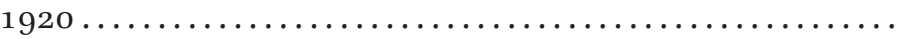

61. "British" Indian Export of Opium to Various Countries, 1911-

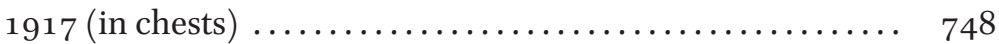

62. Import Trade of Canton, 1833 (in Spanish $\$$ ) ......... 749

63. Prices of opium per chest, in Spanish $\$$ as given in Canton, Macao or Hong Kong, $1800-1880 \ldots \ldots \ldots \ldots \ldots \ldots \ldots \ldots+75^{0}$ 
64. Dutch Opium Import in East Indies by the VOC, $1678-1745$ (selected years)

65. Dutch Opium Import in the East Indies by the VOC and Dutch

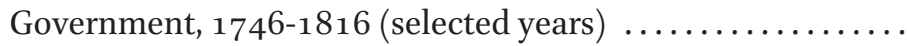

66. Dutch Opium Import by the Dutch Government on Java and Madura only, $1817-1850$ (selected years) $\ldots \ldots \ldots \ldots \ldots \ldots$

67. Total Dutch Opium Imports in the East Indies, 1678-1850 ...

68. Opium performance of the VOC and Amphioen Society (AS),

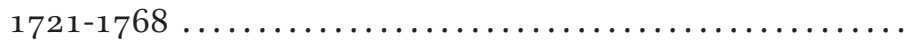

69. Incomes and Expenditures of the VOC in 1795 ( $x$ guilders) ..

70. Accumulated Profits and Losses of the VOC 1613 to 1693

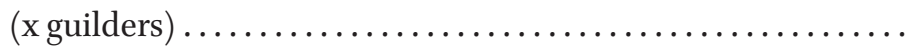

71. The Budget of Governor-General Daendels ca. 1808 (x 1000

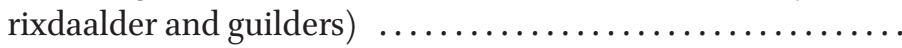

72. Comparison between the periods before, during and after Daendels' government (x 1000 ropij and guilders) ..........

73. Raw opium import, Preparation and Revenue in French

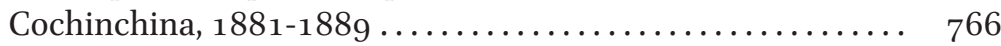

\section{FIGURES}

1. Opium Smuggling into China and Shanghai, $1837-1860$.....

2. Decennial Average Opium Revenues in India, 1798-1936

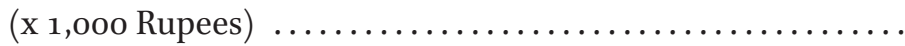

3. Five-year averages of actual and estimated home consumption of opium per 1,00o population in England, 1825-1905 ......

$4+5$. Schematic Diagrams of the Organization of the VOC-General and of the VOC-Asia $\ldots \ldots \ldots \ldots \ldots \ldots \ldots \ldots \ldots \ldots$

6. Opium Factory, import raw opium, 1900-1940 (x 10,00o kilo-

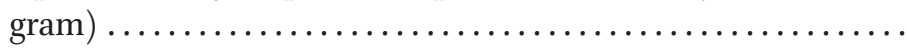

7. Revenue from opium tax farms in Java and Madura, 1816-

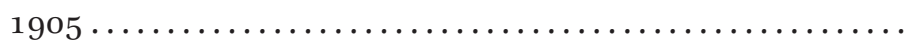

8. Percentage Gross and Net Opium Revenue in the French Colonial Budget of Cochinchina, 1864-1895 ............

9. Total Opium Consumption in Indochina, 1905-1910 and the Consumption per Head per year, $1906-07 \ldots \ldots \ldots \ldots \ldots .418$

10. Opium Consumption in Indochina, $1899-1920 \ldots \ldots \ldots \ldots$

11. Average annual opium price in Singapore, 1820-1901 (Spanish

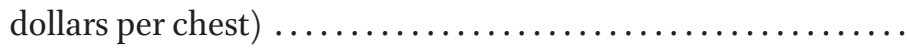

12. Indian EIC Export to China of Bengal and Malwa Opium, 18o9-

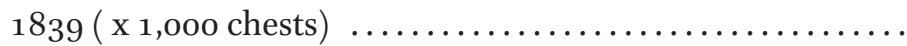


13. East Indies: Production Cost of Opium Factory and Sales Revenue of Opium Regie, 1900-1935 (x 1 million guilders) . . 769

14. East Indies: Production Cost of Opium Factory and Sales Revenue of Opium Regie, 1900-1920 (thail per guilder) ..... 770

15. East Indies: Opium Factory, Production cost, 1900-1940 (x 200,00o Dutch guilders) ................... 770

16. East Indies: Opium Factory, Production cost, 1900-1940 (per

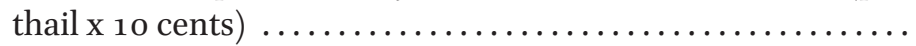

MAPS

1. The global triangle of trade, circa $1820 \ldots \ldots \ldots \ldots \ldots \ldots .60$

2. Sources of Opium Imported in Britain in the 19th Century ... 106

3. East Asia according to Portuguese mapmakers ca. $155^{\circ} \ldots \ldots .148$

4. Sketch-map of North Hindostan showing the Opium districts Behar and Benares and the landscapes of the Malwa and Nepal Opium Cultures, ca. $1880 \ldots \ldots \ldots \ldots \ldots \ldots \ldots \ldots \ldots \quad 183$

5. Octroy area of the VOC during 1602-1795 ............ 205

6. Southasian centers of VOC trade during 1602-1795 ...... 211

7. VOC trading centers in the East Indies during 1602-1795 . . 218

8. Major Dutch Campaigns in Java, September-December $1678 \quad 222$

9. The "Dutch" East Indies, superimposed on a map of the United

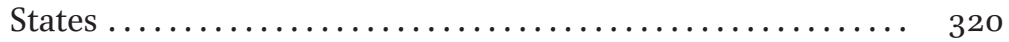

10. The "Dutch" East Indies and their "Zones for the Control of

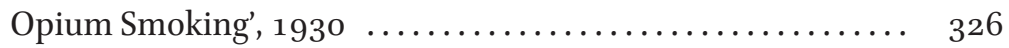

11. Mainland Southeast Asia, $1880-1930 \ldots \ldots \ldots \ldots \ldots \ldots \ldots . \ldots . \ldots 9$

12. Indochinese Zones with different prices of the French Opium-

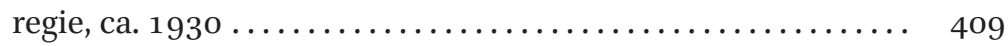

13. Opium Cultivation in Shan State before and after $1963 \ldots \ldots$

14. Prices of Monopoly Opium in force in various Siamese Districts,

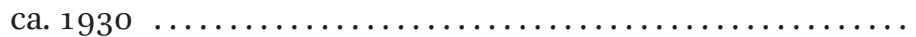

15. British Trade routes in the 19th-century and important areas of Chinese Settlements in the Malay world .......... 462

16. Heroin seizures in the United States, 1927-1928 ....... 584

17. Estimated Annual Opium Production per Chinese Province,

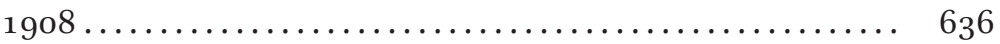

18. Opium Cultivation in China, $1920 \ldots \ldots \ldots \ldots \ldots \ldots \ldots \ldots 696 \ldots$

19. Caravan Routes in the "Golden Quadrangle", ca. 1900 ...... 668

20. CIA Map of International Drug "Pipelines”, November 2009 . . 732 